\title{
Immune checkpoint inhibitors in large cell neuroendocrine carcinoma: current status
}

\author{
Aman Chauhan ${ }^{1}$, Susanne M. Arnold ${ }^{1}$, Jill Kolesar ${ }^{1}$, Hala Elnakat Thomas ${ }^{2}$, Mark \\ Evers $^{1}$ and Lowell Anthony ${ }^{1}$ \\ ${ }^{1}$ Markey Cancer Center, University of Kentucky, Lexington, KY, USA \\ ${ }^{2}$ University of Cincinnati, Cincinnati, OH, USA \\ Correspondence to: Aman Chauhan, email: aman.chauhan@uky.edu
}

Keywords: large cell neuroendocrine carcinoma; high grade neuroendocrine carcinoma; immune checkpoint inhibitors

Received: December 23, 2017 Accepted: February 13, 2018 Epub: February 22, 2018 Published: March 06, 2018

Copyright: Chauhan et al. This is an open-access article distributed under the terms of the Creative Commons Attribution License 3.0 (CC BY 3.0), which permits unrestricted use, distribution, and reproduction in any medium, provided the original author and source are credited.

\section{ABSTRACT}

Introduction: Large cell neuroendocrine carcinomas (LCNEC) are a group of rare high grade neuroendocrine tumors that often behave clinically like small cell carcinoma (SCLC) and are treated as such. No major advancement in the management of these tumors has occurred in the last $\mathbf{3 0}$ years.

Methods: We present a case series of three cases from Markey Cancer center along with a review of 13 published cases in the literature wherein immune-checkpoint inhibitors were utilized in the management of LCNEC.

Results: Immune-checkpoint inhibitors might have clinical activity in LCNEC.

Conclusion: Role of immune-checkpoint inhibitors should be explored in prospective LCNEC clinical trials. We summarize current evidence regarding use of immune checkpoint inhibitors in the treatment of LCNEC.

\section{INTRODUCTION}

Large cell neuroendocrine carcinomas (LCNEC) are a group of rare high grade neuroendocrine tumors that often behave clinically like small cell carcinoma (SCLC) and are treated as such. These tumors can arise anywhere in the body, but pulmonary LCNEC is by far the most common. Patients usually present with extensive disease and have a poor prognosis. Platinum-based chemotherapy is often the treatment of choice, similar to SCLC, but response is short-lived. No standard second line treatment exists. Various combinations of taxane- or irinotecanbased chemotherapies have yielded poor response rates. Clinical trials are few and are difficult to conduct due to rarity of the disease. No major advancement in management of these tumors has occurred in the last 30 years. We summarize current evidence regarding immune checkpoint inhibitors in the treatment of LCNEC.

\section{RESULTS}

To our knowledge, there are only two published case reports and one poster presentation that retrospectively reviewed the efficacy of immune checkpoint inhibitors in LCNEC. We would like to add our single center clinical experience with immune checkpoint inhibitors $(n=3)$ and also summarize the existing published clinical data to date.

Levra et al. presented their data on use of immune checkpoint inhibitors in pulmonary LCNEC at the IASLC 18th World Conference on Lung Cancer in 2017. Ten patients were treated with immune checkpoint inhibitors (9 with nivolumab and 1 with pembrolizumab). Six of the ten showed a partial response and one demonstrated stable disease. Median progression free survival was reported as 57 weeks and the median number of doses of immune checkpoint inhibitor therapy received was 16 [1].

Daido et al. reported 2 cases of LCNEC who received nivolumab as third and sixth line of salvage therapy for progressive metastatic disease. The authors reported a radiological response to immune checkpoint inhibitor therapy but the degree and duration of response was not presented [2].

Wang et al. reported a single case of pulmonary LCNEC in 2017 with an exceptional response to a first dose of pembrolizumab. The patient was continuing 
Table 1: LCNEC patients treated with immune checkpoint inhibitors at Markey Cancer Center, University of Kentucky

\begin{tabular}{|c|c|c|c|}
\hline Patient & Prior treatment & Current treatment & Response \\
\hline $\begin{array}{l}80 \mathrm{Y} / \mathrm{O} \mathrm{F} \text { with metastatic gastric } \\
\text { LCNEC }\end{array}$ & $\begin{array}{l}6 \text { cycles of cisplatin and } \\
\text { etoposide. } \\
\text { Disease progression in liver } \\
\text { three months after platinum } \\
\text { doublet completion. }\end{array}$ & $\begin{array}{l}\text { Second line, off label } \\
\text { nivolumab q } 2 \text { weeks } \\
\text { for past } 6 \text { months } \\
\text { and continuing. }\end{array}$ & $\begin{array}{l}\text { Clinical and radiological } \\
\text { response. } \\
\text { Stable hepatic } \\
\text { metastatic disease. }\end{array}$ \\
\hline $\begin{array}{l}57 \mathrm{Y} / \mathrm{O} \text { with metastatic LCNEC of } \\
\text { lung with brain metastasis }\end{array}$ & $\begin{array}{l}\text { Resection of brain metastasis } \\
\text { followed by radiation, } \\
\text { carboplatin and etoposide X } 4 \\
\text { cycles, intolerance to further } \\
\text { platinum doublet. } \\
\text { Switched to maintenance } \\
\text { pemetrexed X } 21 \text { cycles, } \\
\text { developed toxicity to } \\
\text { pemetrexed. } \\
\text { Switched to off label nivolumab. }\end{array}$ & $\begin{array}{l}\text { Nivolumab } \\
\text { discontinued post } \\
4 \text { doses due to } \\
\text { lack of measurable } \\
\text { radiological disease. } \\
\text { Currently on } \\
\text { observation. }\end{array}$ & $\begin{array}{l}\text { Complete response. } \\
\text { Off therapy for } 15 \\
\text { months now. }\end{array}$ \\
\hline $\begin{array}{l}39 \text { Y/O F with metastatic LCNEC } \\
\text { of lung. } \\
\text { Positive for following mutations; } \\
\text { STK11, AURKA, AXL, MYC, } \\
\text { CCNE1, GNAS, KEAP1, MCL1, } \\
\text { RUNX1, TP53. } \\
\text { High tumor mutation burden and } \\
\text { PD-L1 positive. }\end{array}$ & $\begin{array}{l}\text { Carboplatin and etoposide X } \\
5 \text { cycles. Radiological disease } \\
\text { progression. } \\
\text { Switched to nivolumab based } \\
\text { on molecular tumor board } \\
\text { recommendation. }\end{array}$ & $\begin{array}{l}\text { Currently on } \\
\text { nivolumab q } 2 \text { weeks } \\
\text { Status post } 15 \text { doses }\end{array}$ & $\begin{array}{l}\text { Radiological and } \\
\text { clinically stable disease. }\end{array}$ \\
\hline
\end{tabular}

treatment at the time of publication of the case study so the duration of response cannot be determined [3].

Table 1 describes 3 cases of LCNEC managed at the University of Kentucky with ongoing durable response to immune checkpoint inhibitor therapy.

\section{DISCUSSION}

In 2016, Rekhtman et al. described genomic alterations sequenced in pulmonary LCNEC and, interestingly, LCNEC patients can be subdivided into SCLC and non-SCLC (NSCLC) cohorts based on the genetic signatures of their tumor [6]. This finding implies that treating all LCNEC patients with SCLC regimens might be suboptimal. Immune checkpoint inhibition is a gratifying treatment option especially for NSCLC and could be explored for LCNEC. About $60 \%$ of pulmonary LCNEC do not exhibit the small cell hallmark signature (TP53 and Rb1 co-mutation) which might explain the large percentage of LCNEC patients who are platinumrefractory or rapidly progress on a platinum doublet. Prospective data regarding use of immune checkpoint in LCNEC is lacking but small pre-clinical data sets support further exploration of immune checkpoint in LCNEC.

Fan et al. studied PDL and PD-L1 expression in pulmonary neuroendocrine tumors. Ten out of 80 patients in their cohort were LCNEC. All 10 LCNEC were positive for PD-L1 and 8 out of 10 were positive for PD-1 [4]. More recently, Tsuruoka et al. analyzed PD-L1 expression in 227 pulmonary neuroendocrine tumors, 106 of which were LCNEC. Unlike the previous study, PD-L1 expression was modest (10.4\%). Karim et al, recently reported PD-L1 tumoral expression in 5/24 (21\%) cases albeit 2 cases with only $1 \%$ staining in 1 out of the 3 cores from each patient on the tissue microarray [7]. The variability in percentages noted in these studies may be explained by the relatively small sample numbers of LCNEC cases employed. However, in comparison to SCLC and low grade neuroendocrine tumors where 5.8\% and $0 \%$ of the cases respectively were PDL- 1 positive, LCNEC still exhibit a higher positivity among all pulmonary neuroendocrine tumors [5].

Although the correlation of PD-1 and PD-L1 expression with response to immune checkpoint inhibitor therapy remains under investigation, the presence of PD-1/ PD-L1 in LCNEC is interesting, especially considering the scarcity of treatment options and potential therapeutic targets in this rare and very aggressive malignancy.

Clinical trials in rare tumors are difficult to conduct, hence strong prospective data regarding management of LCNEC is lacking. No prospective data regarding the use of immune checkpoint inhibitor is currently available, but is warranted. 


\section{ACKNOWLEDGMENTS}

The authors thank Catherine Anthony for assistance with manuscript preparation.

\section{CONFLICTS OF INTEREST}

Authors do not disclose any financial or commercial interests relevant to this manuscript.

\section{REFERENCES}

1. Levra MG, Mazieres J, Valette CA, Molinier $\mathrm{O}$, Planchard D, Frappat V, Ferrer L, Toffart AC, MoroSibilot D. Efficacy of immune checkpoint inhibitors in large cell neuroendocrine lung cancer: results from a French retrospective cohort. J Thorac Oncol. 2017; 12:S702-03.

2. Daido W, Yamasaki M, Saito N, Ishiyama S, Deguchi N, Taniwaki M, Daga H, Ohashi N. [Effectiveness of nivolumab in large-cell neuroendocrine carcinoma of the lung - a report of two cases.] [Article in Japanese]. Gan To Kagaku Ryoho. 2017; 44:59-62.

3. Wang VE, Urisman A, Albacker L, Ali S, Miller V, Aggarwal R, Jablons D. Checkpoint inhibitor is active against large cell neuroendocrine carcinoma with high tumor mutation burden. J Immunother Cancer. 2017; 5:75.

4. Fan Y, Ma K, Wang C, Ning J, Hu Y, Dong D, Dong X, Geng Q, Li E, Wu Y. Prognostic value of PD-L1 and PD-1 expression in pulmonary neuroendocrine tumors. Onco Targets Ther. 2016; 9:6075-82.

5. Tsuruoka K, Horinouchi H, Goto Y, Kanda S, Fujiwara Y, Nokihara H, Yamamoto N, Asakura K, Nakagawa K, Sakurai H, Watanabe SI, Tsuta K, Ohe Y. PD-L1 expression in neuroendocrine tumors of the lung. Lung Cancer. 2017; 108:115-20.

6. Rekhtman N, Pietanza MC, Hellmann MD, Naidoo J, Arora A, Won H, Halpenny DF, Wang H, Tian SK, Litvak AM, Paik PK, Drilon AE, Socci N, et al. Next-Generation Sequencing of Pulmo nary Large Cell Neuroendocrine Carcinoma Reveals Small Cell Carcinoma-like and NonSmall Cell Carcinoma-like Subsets. Clin Cancer Res. 2016; 22:3618-29.

7. Karim N, Sendilnathan A, Eldessouki I, Orr-Asman M, Xie C, Wang J, Elnakat H. Immune checkpoint markers in lung large cell neuroendocrine carcinomas (L-LCNEC). J Thorac Oncol. 2017; 12:S1583-84. 